\title{
Poverty and Inequality in the Niger Delta: Is National Economic Empowerment and Development Strategy the Answer?
}

\author{
Macleans A. Geo-JaJa, Brigham Young University \\ Steve Azaiki, World Environmental Movement for Africa
}

\begin{abstract}
The paper examines economic poverty and educational poverty in the Niger Delta, a region endowed with enormous, but misused, resources. The National Economic Empowerment and Development Strategies (NEEDS) is contrasted with other poverty reduction strategies. The blindness of NEEDS to the complex causes of the situation in the Niger Delta is noted. The issues analyzed concern the emphasis placed on market forces, the schemes used to finance education, and the choice of provision of education towards equality. The final section of the article gives a critical reading of the strategy currently adopted to reduce the incidence of poverty in Nigeria and its failure in the Niger Delta. The paper rejects the NEEDS framework of rolling back the state in favor of market forces as an ineffective education and economic plan for an already disempowered and impoverished region. The paper argues for a targeted, broad-based NEEDS strategy that is focused on re-orienting values, reducing economic and educational poverty, creating wealth, and developing a strong state for mobilizing resources for economic empowerment and sustainable development.
\end{abstract}

\section{Résumé}

Cet article examine la pauvreté sur les plans économique et éducationel dans le Delta du Niger, une région nantie de ressources énormes mais mal utilisées. Les stratégies NEEDS (National Economic Empowerment and Development Strategies) se heurtent aux autres stratégies pour la réduction de la pauvreteé. Les auteurs remarquent que les stratégies NEEDS ferment les yeux aux causes complexes de la situation au Delta du Niger. Les problèmes analysés sont centrés sur l'emphase placée sur les forces du marché, les programmes pour financer lèenseignement, et sur le choix des provisions de l'enseignement vers l'égalité. La dernière section de l'article offre une critique de la stratégie présentement adoptée pour réduire la pauvreté en Nigérie et son échec au Delta du Niger. L'article rejète le cadre de travail de NEEDS dans lequel le rôle de l'état cède le pas aux forces du marché. Pour les auteurs, ceci est un plan inefficace pour l'enseignement comme pour l'économie pour cette région déjà démunie du pouvoir et déjà appauvrie. L'article propose pour les NEEDS, une stratégie mieux axée sur les buts et aux bases plus enlargies, et qui est centrée sur la réorientation des valeurs, la réduction des pauvretés économique et éducationnelle, la création des biens, et le développement d'un état fort pour 
mobiliser les ressources capables de créer un pouvoir économique et un développement continu.

"Whether the growing youth population will contribute to economic productivity or become a drag on the social resources hinges crucially on policy decisions to bolster educational investment."

\section{The Challenge}

Since 1999 Nigeria has evolved into a democracy with a modal constitution, and a weak human-rights-centered judicial and legal system. While Nigeria's economy may be stagnating or declining, it is nonetheless a repositioned country on the global platform. On the other hand, the democratically elected government is still faced with the major socio-economic challenges of a persistently high unemployment rate $(29 \%)$, poverty rate $(70 \%$ below $\$ 1$ per day), illiteracy rate (35\%), a dismal Human Development Index (HDI 0.448), and large income disparities (Gini 0.59). The HDI of 0.448 and a Gini coefficient of almost 0.60 illustrate high human depravation and high income inequality respectively (see UNDP 2006: Table 1; United Nations 2006: Table 15). Interestingly, Nigeria's free-market economy with minimal spending on social services and welfare has high income inequality with a small proportion of society controlling most of the wealth. This is highly indicative of social service problems, a rampant explosion of slums, and the low quality of education.

The educational system is hampered by problems of poor access, high repetition and drop-out rates, poor infrastructure, and inequity among different regions, income groups, and gender. The introduction of the Universal Primary Education (UPE) program has resulted in a dramatic increase in enrolment; however the quality of education, low in the first place, has deteriorated further. The widespread deprivation and educational poverty suggested by the social indicators is further confirmed by an analysis of the severity of poverty, the educational poverty profile, and the social exclusion in the Niger Delta. The government is also faced with the reality of a dual economy and its constitutional obligation to ensure the provision of basic social services for all citizens, especially to the most marginalized of the majority: women and children. These factors of economic disempowerment are caused by lack of productive assets, lack of access to social services, and infrastructure and inadequate skills, and manifest themselves in the inability by the majority of citizens in Nigeria to control their economic destiny. Clearly, being one of the least developed countries in the world, Nigeria, is characterized by widespread poverty. But when the new government assumed office, it proclaimed that poverty alleviation and economic empowerment was going to be its operative development philosophy.

Today, the government argues that Nigerians have become more economically empowered, more equal, and that the number of people faced with deprivation has fallen for the first time in more than two decades as a result of the transition from pro-active state intervention to the conventional macro-economic

76 Canadian and International Education Vol. 36 no.1 -June 2007 
framework of the National Economic Empowerment and Development Strategy (NEEDS).

The NEEDS is organized into pillars, which represent a grouping of various goals, objectives, strategies and activities that represent a specific facet in efforts to reduce poverty and empower citizens. The central philosophy of the NEEDS is poverty alleviation, economic empowerment and capacity-building. The National Economic Empowerment Development Strategy (NEEDS) has the goal of bringing about social-economic transformation to enable the poor in Nigeria to be in a position to make their own decisions that will determine and control their economic destiny by making them share in the ownership, control, and management of the country's wealth, thereby increasing their participation in the formal economy in Nigeria. Central to the objectives are areas in human resource development, employment equity, private sector-led growth and enterprise development, and investment in the social sector for human capabilities.

The macro-economic framework for economic reform in Nigeria is NEEDS. This is Nigeria's own Economic Transformation and Poverty Reduction Strategy encapsulated in market-driven growth. It requires deficits to be wellmanaged and large deficits to be reduced to sustainable levels. Thus, it is postulated that progressive trends in the country are in large part due to the NEEDS program which makes for better governance and more efficient use of resources. In fact, NEEDS framework is considered highly progressive, liberal, and profoundly committed to stimulating private investment, and creating adequate and varied possibilities to promote and develop a generation of productive citizens. Thus, NEEDS is not simply a moral initiative to redress the wrongs of the past. The government argues that it is a pragmatic growth strategy that aims to realize economic potential. Thus, it is presumed to be the solution for lagging regions, specifically the Niger Delta. It is expected that the democratic nature of NEEDS will lead towards social liberalism and national identity. As was the case with the policies of government that have created a dual economy, the consensus is that the policies of the present administration have systematically constrained productivity in the Niger Delta which has resulted in very low incomes and food insecurity for households. These findings provide evidence that despite several on going reforms, these households, collectively known as Ijaw people, have not benefited from the enormous wealth that has been generated by oil and the many other economic gains reported by government. The magnitude of deprivation and the level of inequity that exist between the Niger Delta region and non-oil producing regions continue to widen. This divide has caused much poverty and suffering - and a profoundly ailing economy.

From the first discovered oil well in 1958 at Oloibiri to the present era of commercial crude oil, the Niger Delta has been fraught with problems that have led to systematic social exclusion. This condition remains true today, as many communities lack infrastructure and livelihood services despite various government interventions aimed at mitigating them (Douglas, 2002). Arguably, the poverty in the Delta region reflects long-held feelings of social exclusion and various cultural asymmetries that range from economic and social to cultural and 
political. Social exclusion has four main causes: poverty, unemployment, political exclusion, and non-sustainable modes of development. These indicators affect living standards of the present generation, the organization of civil society, and the prospects of the next generation and also have direct bearing on the challenges of environmental sustainability.

This paper argues that although over the past years there have been policies aimed at encouraging growth and eradicating poverty, the reality is that exclusion and human deprivation still remain a crucial problem in the Niger Delta. It was the intensification of educational poverty, as well as economic deprivation that led to the implementation of NEEDS, specifically in the realms of political and societal reengineering. In reality, the NEEDS Act of 2004 followed standard prescriptions of liberalization, privatization, and deregulation, with little attempt to link these policies to a balanced scorecard to measure human progress in the following areas: empowering people, improving social service delivery; and reducing or stabilizing poverty. Clearly, it integrates governmental programs across all sectors, as it focuses on transparency, accountability, and inclusiveness in the running of the country with public ownership being gradually replaced by private ownership. But the economic component of the transformation process seems to be more difficult in some regions than in others. It is these aspects of NEEDS, that make one skeptical of the adequacy of this neoliberal type reform, circumstances in which a majority of the population is economically and politically marginalized while a minority is privileged, either through its economic, party-political, or State - bureaucratic position in society.

NEEDS is evaluated in the context of its action plan to maximize poverty reduction given the available resources. The articulated poverty alleviation strategy at best provided only a general framework for implementing a poverty alleviation program that does not address issues of social rights and empowerment in the Niger Delta. Throughout the paper, the ability of NEEDS to empower the masses and to encourage economic development is examined. The paper aims to see if the relation between what NEEDS has done in the education and poverty sector differs from what other strategies have done.

\section{Concepts}

The paper's argument is founded on an analytical perspective that can be summarized in two basic propositions. First, poverty as characterized by social exclusion is conceptualized through different types of educational poverty: educational quality; educational exclusion in terms of access; illiteracy; and inequalities of the educational system. Education quality refers to the extent that an education system is able to achieve the generally accepted goals of education, central to which is knowledge and skill development (Fuller and Clark, 1994; Heyneman, 1997) Second, difficulties were encountered when the Presidential Economic Team (PET) did not fully understand the organizational underpinnings of educational poverty that had been decentralized nor did macro-economic framework add up to a coherent strategy for broad-based economic growth. Clearly, government must not continue to engage in development as "business as

78 Canadian and International Education Vol. 36 no.1 -June 2007 
usual" at the expense of social inclusion. Consequently, what the government does or fails to do in initiating policy interventions will directly affect wealth creation and livelihoods in the Delta

In situations in which basic human rights are not guaranteed, poverty becomes a problem of injustice and breeds inequality. Indeed, the widespread anticipation that the efficient private sector-led development aspects within NEEDS would assist those at the margins of society to grasp opportunities and to establish or reestablish them in the market has been illusory. In education, as in other areas of the social sector, recent calculations suggest that the most vulnerable groups have lost more than they have gained because of the drastic reduction in social sector budget. This has in turn exacerbated problems of poverty and educational poverty in this group. The lack of an unbiased evaluation procedure and the repercussion of neoliberal orthodoxy, which has had enormous negative feedback on the Niger Delta, confirm the need for the changes in the NEEDS reforms that this paper sets forth.

The paper is divided into the following five sections. The first section sets the stage for core objectives and the reasons behind this paper. The second section conceptualizes different perspectives of development. This section also spells out some general policy implications of various strategies and articulates reflections beyond them. It also examines the impact of NEEDS on social exclusion, meaning economic and educational poverty, and human development in the Niger Delta. The fourth section offers suggestions on how to better target policies to improve outcomes and achieve sustainability. The last and final section is an understudy of the Nigerian Economic Empowerment and Development Strategy (NEEDS) as it impacts the Niger Delta. This section also offers suggestions on how to encapsulate a broad-based NEEDS procedure that supports sustainable outcomes and achievements.

\section{Development: The Need for Transformation}

It is important when considering the evidence and options on alternative development policies to have a comprehensive picture of conceptual terrain. Many of the recent discussions in this area have engaged in conceptual shortcuts. The following are several key distinctions and issues that should be considered.

\section{What kind of Development?}

The special circumstances in which most developing countries find themselves require programs that recognize that poverty is consistent with social exclusion. This understanding depends on the commitment of the government to actualizing its responsibility to the social charter while ensuring adequate public spending for human development activities. These needs have always been apparent for effective programs and are standard the world over.

Although various poverty strategies have been implemented recently, surveys reveal that the main causes of poverty include insecurity to life, lack of adequate access to capital and education, and lack of information. Even in the nogrowth era of the $1980 \mathrm{~s}$, these same problems were given explicit attention 
through pro-active state policies. Success was achieved as it was ensured that government played a major role in mobilizing funding that was placed at the disposal of both the private and public investment. But today, poverty associated with other social factors and historical patterns of exclusion has become an added challenge to the government's retreat from the social sector. Consequently, as the governments slips into a vicious cycle of social dumping through decentralizing the government's responsibility, poverty and deprivation are magnified in society (Rio+ 10 News 2002:1). Herein lies the reason for the things that the government does or fails to do at the society level concerning matters that directly affect the lives of citizens whose social and political capital are eroded. This paper postulates that social capital is made up of "norms and networks" that facilitate collective action. With its important link to education, social capital can be argued to be an enabler of the productive use of human and physical capital. The NEEDS framework that defined the various categories of the poor, the constraints they face, and the strategies that government was to adopt is anticipated to produce different results from past development strategies. The question then is, why the high expectation on NEEDS? The truth is that unlike the other development policy frameworks, NEEDS contains a detailed and prioritized set of activities that stakeholders have agreed will maximize poverty reduction given the available wealth generated from oil. It also has stakeholders' ownership and an action plan that clearly allocates responsibility for the undertaking of the various activities to lead and support institutions.

\section{Poverty and Development Defined}

Development, when defined as a set of interdependent processes through which a traditional social structure is transformed into a modern social structure, must be recognized as containing diverse needs and experiences in different countries. Within this framework, approaches to development have been formulated to take into consideration the differences in the levels of modernity and the impetus for the creation of a distinctive sense of national identity. The debate of such an approach centers on the government's role in ensuring the enabling social charter.

This paper concentrates on two broad developmental procedures to explain the social exclusion experienced in the Niger Delta. The first procedure is development that puts social factors and the expansion of people's capabilities at the center. For this approach, equitable distribution of resources is seen as the optimal means for mitigating poverty characterized by historical patterns of exclusion, lack of education and skill, and vulnerability to economic and social capital. Therefore, to address the many dimensions of human deprivation, the strategy should be reform through equitable income redistribution and rapid expansion of the social charter and services.

Townsend (1993:79) in distinguishing between two types of deprivation - material and social — noted that the "subsistence concept" of poverty minimizes the range and depth of human need. Amartya Sen in his book Inequality Reexamined developed a comprehensive approach to poverty which goes beyond economics. At the heart of Sen's approach is the notion of

80 Canadian and International Education Vol. 36 no.1 -June 2007 
"capabilities." These are opportunities to reach a certain level considered acceptable for essential human achievement or to achieve valuable "functionings" (Sen, 1992: $38 \&$ 110). These concepts have a major focus on social interactions rather than economics and acknowledge that development is more than just income growth; therefore, it provides more opportunities for incorporating human dignity and social factors into economic models. This point emphasizes the need to combat several key tenets of neo-liberal orthodoxy before national policymaking can be re-oriented towards people-centered broad-based strategies. This, of course, is not a formula that can be applied mechanically, but it does contain ingredients that distinguish it from a market approach to development.

The record of macroeconomic framework which ignores the development of valuable capabilities that are vehicles for transmitting values and attitudes for addressing the many dimensions of poverty remains controversial (World Bank 2005). The thesis hailed by its supporters as the only solution to crises that have buffeted developing countries states that the presence of a pro-active state has been excessive, and that the market is insufficient. Furthermore, as comprehensive as market-led reforms (and conditionalities) have been, they have not added up to coherent strategies of broad-based economic growth. This explains the privatization and deregulation movement now so common in Nigeria. The transformation so far undergone by the economy has frequently metamorphosed from instrument to divine fiat with the push for a reengineered society. This substantive framework of NEEDS deploys macro-economic stability arguments for opening up national economies, as well as proposing a tightening of social sector spending on behalf of the global economic managers.

Presumably, these are not bad economic tenets, but their applicability to certain environments should depend on the stage of educational development and power relations between engaging parties (Frank, 1966; McMichael, 1996; GeoJaJa [and Mangum or with Yang?] 2003). In this procedure, there is only one way to salvation: market fundamentalism. This approach has a debilitating impact on the ability of countries to retain domestic saving and direct this saving to productive private investment. In turn, even if resulting in economic growth, this investment is not necessarily development, and therefore should not be confused with human development. In Nigeria, this policy is characterized by inflation outbreaks, official or partisan misappropriation of public funds, and economic differentiation characterized by growing regional differences, among other things. These conditions are looked upon as the major threats to current political democratization and the slowly improving corruption indicators. Actually, this interpretation represents a modern alternative provided by NEEDS that is narrowly linked to neoliberalism.

Clearly, the two alternatives are no more mutually exclusive than identical. If there were any common ground between them, it would be in their identification of contradictions attending to development in a competitive globalizing world. A comparison of the two approaches shows a fundamentalist belief in the rationality of an open economy, but the level playing field that is supposed to drive this operation is a fiction at best and an assertion of the power 
of comparative advantage at worst. Unlike the fundamentalist, the traditionalist, if we are allowed to call them such, applies a people-centered approach that begins from the position of people and community negotiating the complexity of ethnicity and cultural relations connecting them to their social and economic contexts.

\section{Development Triangles and "Nested Inequalities"}

The economic prosperity in the 1970s was followed by social and economic crisis as debt skyrocketed and disease grew. These nested inequalities in society have continued to be a significant challenge to government. Economic reforms while contributing to growth have further compounded the spread of various forms of social and economic insecurities. This will be discussed in detail later in the paper.

The crucial point here is that the dated various reforms, with the convenient addition of some new words such as transparency, accountability, and inclusiveness has visibly being implemented. Under the guise of comparative advantage and trade liberalization, the social and economic security of citizens has been threatened as growth has come to be characterized by slow consumption, low income, inadequate access to employment opportunities, widespread educational poverty, as well as entrapment in a vicious circle of poverty. Stewart et al. (2000), note that countries adopting a people-centered approach tend to enjoy higher rates of economic growth along with improved social factors. Geo-JaJa and Mangum (2003) also recognize the fact that pro-active state intervention in key social sectors such as basic education and healthcare is instrumental in yielding not only productivity gains, but is also associated with high human development outcomes. Therefore, policies of false growth should be rejected as well as denouncing false federalism contained in the privatization of politics, or homogenization that does not celebrate cultural diversity. To be initiated are interventions that foster social and cultural integration of the citizenry.

According to the World Bank and UNDP, anti-state neoliberalism in recent economic thinking has led to disempowerment, denial of fundamental human rights, and the on-going cycle of poverty in Nigeria (World Bank, 2005; UNDP, 2006). In spite of some gains, the Bank and UNDP observed that educational poverty had additional negative effects on poverty and human development in the Niger Delta. Perhaps the greatest contradiction in the Niger Delta is that the macro-economic framework has "a cash income" effect that is insufficient to cover minimum standards of basic needs, thus further hampering systematic growth in subsequent years. In fact, these denials have served as an additional source of tension and conflict within the society. With previous approaches that did not address society's unbalanced social charter and development, there was a need to understand how social protection differs under the NEEDS model, as the insincerity of government in its commitment to ameliorating life-threatening and deteriorating social fabrics leave citizens no other better course of action than to demand for resource takeover (Azaiki 2003). 


\section{The Unchanging Face of the Niger Delta with NEEDS \\ Landscapes of the Delta Region}

The Niger Delta region covered in this research is rich in natural resources with large oil and gas deposits, extensive forests, good agricultural land, and abundant fish resources. The history of the region is characterized by blatant disregard for resource rights and basic social needs, and ecological hazards associated with the "politics of oil." In essence, this means making decisions or falling back on readymade choices and institutions, rather then putting in the necessary efforts involved to analyze or uncover the relations of policy action on outcomes.

The ethnic minorities that occupy the region have their own distinctive histories and cultures and are located in different socio-ecological zones. They are surrounded by the release of harmful gas into the atmosphere, the cutting down of forests, and the polluting of fishing waters and farmlands with oil from neglected broken pipelines. Clearly, the above conditions coupled with deprivation associated with anti-social activities and mutual emptiness has contributed much violence and conflict which undermine social and economic progress (UNDP 2006).

It may be concluded that as multinational oil companies celebrate record excess profits, communities ostensibly blessed with the curse of oil languish in squalor, lacking jobs and basic social services (Sala-I-Martin and Subramanian 2003). What they do have in abundance is farm lands that are rendered useless and rivers and waterways, once well populated with marine life, that are now barren from decades of environmental pollution.

\section{The NEEDS and Educational Poverty in Niger Delta Region}

Education is the best anti-poverty strategy and the best economic development program (McGinn and Cummings, 1997; Jolly 2005, UNDP 2006). Education is also essential to overcome social exclusion and voicelessness, but many families are denied access or unable to afford this critical and fundamental human right. All children should have free access to quality basic education within an equitable system. Schools should be places where children's rights are respected, injustices are challenged, and lives are transformed. By attending school, children acquire the confidence and knowledge to better access and make use of information that can improve their functionality in society. The challenge facing the government today is to avoid further disintegration of the educational system in the region and to recapture previous levels of education quality and access that will eradicate growing poverty.

According to the UNDP, the dearth and severity of educational poverty is much higher in the Niger Delta than in any other relatively resource endowed region in the country, and has increased significantly since 2004 (UNDP 2006). Internal efficiency indicators of education illustrate this situation. The rate of school entry is stagnating or even diminishing despite the introduction of Universal Primary Education (UPE). The coverage and quality of UPE have remained perceptibly weak as evidenced by poor retention and high drop-out rates. Although illiteracy is slowing receding among youths, adult literacy is at 20 
percent. Geo-JaJa (2004) and ActionAid International (2005:35) have attributed these negative effects to the decision by this administration to adopt the policy of privatization, shifting the burden of education from central government to lower tiers of the government and households. As a result, there has been a secular decline in public investment since 1999 when measured as a percentage of GDP. Furthermore, in jeopardizing the right to free, quality education, inequity is also increased in access and achievement. From a poverty perspective, overcoming the obstacles described above will require political will, national leadership and increasing efforts mounted across all domains, including schools, but not limited to schools alone.

Clearly noted is that all the gadgetry in the world cannot equal the impact that a skilled and dedicated teacher has on a student, even in the most rural, impoverished community. Politicians' commercial interest in technology should not be the main priority in education. Teacher intervention programs are necessary conditions for quality education. These facts show that the federal government must not disappear as it undertakes economic reforms. Instead it must accept a new role as a supporter of neo-liberal economics by ensuring that public spending is directed to basic social services. This will guarantee effective use of public and private investment to compete successfully in building human and institutional capacity and to sustain productivity.

\section{Economic Opportunities}

Unlike many other regions, the existing economic reality in the Delta is that there are limited economic opportunities, especially for young people. For instance, there are few employment opportunities in the formal sector. For most, the only option is to seek work in the "informal" sector, an area of the economy operating outside formal government regulations. There are few broad-based public investment programs that prepare young people to thrive in the informal sector, leaving them without basic livelihood skills, such as how to develop a business plan, research what products to sell, market a business, and keep the books. Faced with these shortfalls, they become frustrated as well as disillusioned. They dropout of school and become more preoccupied with survival than they are with their education as there are no formal jobs for which to prepare. The significant consequences of such illiteracy and exclusion are endemic human deprivation and growing civil unrest that bedevil the region.

Inequality at the Starting Gate

Inequality at the starting gate arises because of the way social contracts and opportunities are distributed. This situation is created and sustained, lessened or made worse, by a myriad of patterned and predictable institutionalized policies. For example, a region which contributes 98.54 percent of export revenue and almost 80 percent of national wealth, receives just only 17.3 percent of allocation, while regions that contribute practically nothing enjoy the fruit of the other contributors' labors (Azaiki 2003). This is a further attestation of some of the "nested inequalities" that emanate from the "politics of oil." In addition, it is clear

84 Canadian and International Education Vol. 36 no.1 -June 2007 
from the above data that the developmental rights and livelihood of the Niger Delta people have been sacrificed for the sustenance of the Nigerian Federation.

With the skewed resource distribution and the framework of education decentralization, most children in the Niger Delta face years of schooling underneath trees or in old buildings badly in need of repair. Other challenges include reduced availability of instructional materials and lower school participation rates. But in contrast, children from most other regions enjoy stateof-the-art school buildings and opportunities to participate in quality education. Clearly, the inequality begins at the starting gate, as children from the underprivileged regions learn that they are "not wanted" and their education does not really matter. As Geo-JaJa (2006) has argued while discussing social justice:

.... it is useful to determine quantitatively the relationships between the economic carrying-capacity of lower tiers of government before implementing a policy of education decentralization. This system of school funding without proper determination of a region's carryingcapacity .... makes room for social injustice, which leaves a mark long past the time children graduate.

In understanding nested inequalities of our times, if the objective is moving the economy onto a high-growth path, increasing its competitiveness and efficiency, raising employment levels and reducing social vulnerability, strategies must not limit any potential, as every individual must be allowed to contribute and enjoy growth. From the above analysis, we can clearly state that social exclusion, educational poverty, in the region are not fundamentally technical but rather moral and political, and therefore needs an approach that is embedded in love and compassion. It is only when and if development strategies address these factors holistically that the possibility of the permanence of social and economic exclusion could be achieved. The question, therefore, becomes, how can NEEDS, which only addresses quantitative measures be able to capture non-measurable factors?

\section{Slower Growth and Investment in Human Development under NEEDS}

This section examines the relationship between NEEDS and development as embodied in the Niger Delta. It treats NEEDS as central theoretical concepts in any serious analysis of the problems and prospects of the Niger Delta. This paper rejects the prescriptions of rolling back the state in favor of private sector as inappropriate for Niger Delta equal integration into Nigeria's development. The major thrust of its argument is that in a state of "nested inequality," selective and targeted coordinated state interventions are necessary for guiding and harnessing private and public sector investment for achieving desired level of development objectives both in the Niger Delta and in the nation. The authors therefore regard the creation and nurturing of effective state capacity for structural transformation of the region as prerequisites for balanced and mutually beneficial development. As such, they call for the deliberate creation of popular democratic peoplecentered development approaches so that growth benefits do not accrue 
disproportionately to certain regions and segments of society at the expense of the broad masses. The evidence provided so far does support the trend of marked differences in the standard of living and of divergence of economic performance in the Niger Delta when contrasted with less resource-endowed regions.

Human development indicators in Nigeria are among the worst in the world. Per capita income is below 300 dollars; the problems of poverty and illiteracy are widespread and worsening; and distribution of income and social services is very unequal. These indicators of poverty and human deprivation persist despite some economic gains in the $21^{\text {st }}$ century. In response to these socioeconomic conditions, in 2004 the government placed eradication of poverty and the empowerment of Nigerians as top priority and initiated the NEEDS program. This no doubt created an increased need to promote understanding of the magnitude and the multi-dimensions of social exclusion and human deprivation in the country. Towards this end, the patterns of poverty, human deprivation, and educational poverty found in the Niger Delta is analyzed against NEEDS framework as a solution.

We raise doubts as to the government's claims that the number of people living in extreme poverty in Nigeria or in the Niger Delta has fallen substantially and that income inequality has fallen over the same period, after rising for many decades. All these successes are attributed to NEEDS. But evidence on the ground does support the trend of marked differences in the standard of living and of divergence of economic performance in resource-rich Niger Delta when contrasted with less resource-endowed regions or with the national condition. From these facts, there is little doubt that policies so far implemented have not succeeded in many ways to mitigate the striking social inequalities, insufficient investment in education, healthcare, housing, human security, etc. (UNDP, 2006.) Today, it is suggested that more than 85 percent of Deltans live on less than 20 US cents a day. Conditions in the region have reached life-threatening proportions as the share of the population subsisting on less than $\$ 1$ per day increased from close to 36 percent to just less than 75 percent in 2006 . This increase came two years after the inception of the NEEDS reported a UNDP independent evaluation (UNDP, 2006). Furthermore, the UNDP and the World Bank submit that macroeconomic frameworks without adequate safety nets have had limited impact based on its narrow conceptualization, which appear to mostly address the economics aspects of the problem (IMF, 2004; World Bank, 2005; UNDP, 2006). The UNDP report indicated that macro-economic framework believed by the government to make a significant contribution towards reengineering the economy should have sought to widen people's choices and open opportunities in productive sectors (UNDP 2006). These key findings corroborate what ActionAid International and others had previously found in their own studies that led them to call for a framework concentrating on people rather than developmental artifacts (Stewart et al, 2000; Jones and Hardstaff, 2005; World Bank, 2005; UNDP, 2006). This is clearly representative of the inconsistency between the ambitious attempts at expanding educational coverage with UPE in the region and the failure on the part 
of educational systems and socioeconomic processes to retain a substantial number of children and adults in the educational cycle.

As a short- and medium-term program (2003-2007), the government argued that NEEDS is a necessary measure for increasing growth prospects through programs that are deliberately targeted to address the marginalization of the poor majority by substantially increasing access to and the efficient use of productive assets. It is argued that such a strategy that is both a political and an economic imperative is an investment in democracy for prosperity and security over the long term.

In this section, the paper attempts to create an understanding of NEEDS and its contribution to human development. This section will also use secondary data to validate the inescapable conclusion that poverty and human insecurity have accelerated significantly in the Niger Delta under NEEDS. The paper strongly concludes that biases seem to have crept into government statistical attitudes. It is imperative that government biases be corrected since the conclusions drawn from these faulty data may influence economic policy in the wrong direction. Although NEEDS pledges "faithful implementation of free and compulsory primary education, it supports transfer of costs to households and consideration of more appropriate pricing of facilities and services is in stark contrast to the Universal Basic Education Act 2004" that is to drive NEEDS (see the detail report of Action Aid International 2005). At the tertiary education level, the policy of "right-seizing" used to commodify education has the drastic effect of increasing inequity in access and achievement. The above assertions are attestations that despite the implementation of NEEDS, no significant improvement in curbing devastating social tension, corruption, or the debilitating economic and educational poverty in country or in the Niger Delta could be claimed.

\section{Separate and Unequal Even after the NEEDS}

The evidence of the reversal experienced in the region since implementing NEEDS goes a long way towards underscoring again a monumental failure of government to social charter. The inability of NEEDS to turn its mission into practice clearly suggests a mismatch between the commendable ideal of providing free regional-level fixed interventions. This is bitterly ironic, as Nigeria swallows the unrealistic neoliberal orthodox policies and thereby experiences low and declining levels of education and social participation coupled with a worsening income distribution with slow or no growth in real wages. To ameliorate these unnecessary negative effects that have made a nation rich in natural resources to remain impoverished, the government should rather seek to consider the individual economic circumstances of individual regions and avoid adaptation of a "one cap fits all" policy. This will engender local ownership and enable people to determine feasible economic priorities in a federated state. The foundation of any strategy is stakeholder ownership and micro-level interventions which should lead to institution-building and empowerment - including human rights, freedom and popular participation with consent. This is NEEDS largest setback as it neglects 
the usage of locally available tools and services, does not integrate tradition with modernity and lacks appropriate mechanisms for integrating the traditional expertise of the people in related sectors. These shortcomings underscore the importance of implementation of any kind of reform in a wider-broad context of social protection of citizens. As such, Nigeria's drive for economic development require a NEEDS strategy that provides adequate safety nets, that guarantees the civil, political, and social rights of the citizens while creating a sense of belonging for all citizens. In this scenario, surely policies need to move beyond a macroeconomic framework, which places a premium on expanding the current industrial base through complex manufacturing, beneficiation and knowledge based production, to addressing accumulation paths based on adding the factor inputs of the majority into the economy. A range of interventions (which include education, better workplace organization, and human development support) beyond the basic production process are thus required to enhance human development and competitiveness.

\section{Less progress in Education Outcomes under NEEDS}

Economies that increase the participation of its people in production through education equity, skills development, and social pacts between government, labor, and business, among other interventions, are more likely to become competitive. In contrast, controversial tight fiscal and monetary policies of a macroeconomic framework have not spurred education as a human right nor have they reduced poverty, as has long been claimed by the government (World Bank 2005). As was explained earlier, they are diametrically opposed as the former stymied the realization of public and private investment into education. The impact on education has been cutbacks in the overall budget allocation to the sector, reductions in the number of teachers who are employed, and the miserly salaries the remaining teachers are paid. To compensate for these education inputs shortfalls, the governments have embarked on hiring non-professional teachers as well as allowing class sizes to rise to levels where no teaching can take place. Important reforms to improve the quality of education are sacrificed due to centralization of decision making and decentralization of funding responsibility by the federal government. Appropriate interventions or special initiatives to ensure that all children have access to education, especially those presently excluded (children living in remote rural areas, the extremely poor, etc.) are not being fully implemented.

Clearly, with the incoherence in program coordination and shifting the responsibility of education are at the core of social vulnerabilities faced by Niger Deltans. The NEEDS only offers a politically correct solution. It is important to note that in the long-run, no economy can grow by excluding any part of its human capital. Thus, an economy that is not growing cannot integrate all of its citizens in a meaningful way and will not benefit from the multiplier effect of their human capabilities. Consequently, the narrow mechanism and incoherence of a macroeconomic framework and micro-relevant structural reforms cannot 
guarantee social inclusions basic foundation-education equity. Herein lies the real challenge of NEEDS.

In a random interview of civil society groups in the Niger Delta in 2005, similar concerns were raised about the need to consider the NEEDS framework in respect to local and regional educational goals. In terms of the importance of primary education, an important educational issue concerns the role of the government in providing and financing education. Broadly speaking, it can be said that while countries have relied on governments for the supply side of education, Nigeria has relied on market mechanisms to regulate the organization of schooling. This does not mean that there has not been any state intervention in the sector. This means that in general, Nigeria has kept a relatively weak government involvement in the financing and directing of operations in the education sector. As the invisible hand of market forces replaces the visible hands of the public sector in education, it just has not positively impacted access to education or quality of education, nor has it reduced bureaucracy. Some other negative feedback effect of privatization revolves around inefficiently infrastructured education system that has further compounded the already existing internal efficiency indicators of education in the region. However, it has become obvious that the tenets of NEEDS are inconsistent with empowerment and building human capabilities as part of its main goal of minimizing the role of the state and transfer basic education responsibilities and costs to the private sector and households. Essentially NEEDS has created a parallel system of education in the private sector which affects the quality of education and creates greater access inequalities in the education available to citizens of the Niger Delta. With a strong government, quite a different outcome both in terms of coverage, quality and student achievement can be achieved.

Under the NEEDS framework, the government has a purely regulatory role as education at all levels is now a commodity. As a result, NEEDS has deeply impacted the right to free, equal, and high quality education, thereby excluding some citizens from participating in growing the economy and denying them from being integrated in the economy in a meaningful way in the long-run. In this and other instances as cited in this paper, macro-economic frameworks have not been able to address social deprivation factors such as humiliation, oppression, and marginalization experienced in the Niger Delta. They have also been unable to calm frayed nerves and douse the alarming tension that is turning the entire region into an irredeemable catastrophe. As in past years, it has not proven to be an effective tool in the attempt to influence social exclusion and human development. In fact, it appears to be fixing the wrong problem. What is missing in the Niger Delta are human capabilities, the establishment of systems for efficient management of resources, and basic physical infrastructure.

Confirmed so far from analysis is the severity of poverty and human deprivation in the Niger Delta and indications that poverty eradication and development strategy as deepening growth-oriented policies, improving coverage and quality of basic social services, and establishing cost-effective safety nets with pro-state interventions need to be the priorities for Nigeria's leadership. This 
paper's authors find the narrow mechanism of NEEDS as inadequate for the scale of a problem which requires broader-based measures and more forceful transparent implementation than has taken place so far. These are the challenges that face policymakers. Finally, the authors question whether Nigeria's leaders and the ruling dominant party were true to their collective rhetoric for NEEDS being a double-edged sword or whether they themselves implemented this individualist, privatized strategies for achieving greater benefits for themselves. We conclude by stating that NEEDS' main flaw is with the government trying to balance two pressures - its desire to be part of the world culture, in part by aligning with a neoliberal orthodox economic and education model, and the government's desires to use the education system to exhibit national differentiation at a time when national identity building is most needed.

\section{Conclusion: NEEDS Has Been Associated with Poverty and Educational Poverty}

This paper examines the incidence of educational poverty and human deprivation in the Niger Delta region. The paper argues that NEEDS' macro-economic approach as a necessary measure of fiscal balancing and economic openness should seek also to consider the special economic circumstances of individuals as well as regions in order to avoid the adoption of a "one cap fits all" policy. This consideration captures unique local problems while engendering stakeholder ownership. As a complementary alternative approach, it is suggested that as macroeconomic frameworks have had limited impact in generating meaningful economic development, a complementary alternative is macro-relevant structural reforms and education, which serves as the best anti-poverty strategy and the best economic development program implemented simultaneously with NEEDS in an integrated manner.

To capture the depth of poverty, educational poverty, and human deprivation in the Niger Delta, NEEDS must move beyond privatization and liberalization policies. It should address accumulation paths based on empowering the masses and adding the factor inputs of the majority into the economy. In this respect, if the share of public spending on education is of high priority, with a given fiscal effort, the people of the Niger Delta region could become educationally empowered and economically sustainable. This paper, therefore, argues that if citizens are to mobilize around the NEEDS framework and add value to the economic activities of the Niger Delta, the government must empower Deltans through the strengthening of institutions responsible for equipping people with the requisite skills and resources to enable them to actively participate in economic empowerment activities

In sum, the paper has examined the NEEDS facets and its most salient components along the lines of poverty, empowerment, and basic education while considering a collective good in the Niger Delta. The main conclusion that emerges from this study is that the NEEDS framework as followed by Nigeria did not achieve the desired objectives. It imitated policies mechanically that had been

90 Canadian and International Education Vol. 36 no.1 -June 2007 
implemented in other countries without due consideration to history and cultural factors unique to Nigeria.

\section{References}

ActionAid International Nigeria. (2005). The impact of IMF Policy on the Achievement of Education Millennium Development Goals in Nigeria ActionAid International Ethiopia. (2005). Study of Impact of IMF Conditionalities

Azaiki, S., (2003). Inequities in Nigerian Politics: The Niger Delta, Resource Control, Underdevelopment, and Youth Restiveness, Yenagoa, Bayelsa State, Nigeria: Treasure Books.

Douglas, O. (2002). Poverty Reduction and Youths in the Niger Delta, paper presented at the Center for Democracy and Development (CDD), Port Harcourt, Nigeria March 2002.

Frank, A. G. (1966). The Development of Underdevelopment. Monthly Review 18(4): 1731

Fuller, B., and Clarke, P. (1994). Raising School Effects While Ignoring Culture: Local Conditions and the Influence of Classroom Tools, rules and Pedagogy. Review of Educational Research 64 (1): 119-157.

Geo-JaJa, M. A. (2006,). Educational Decentralization, Public Expenditure, and Social Justice in Nigeria', International Review of Education, 52(1-2) 125-148.

Geo-JaJa, M. A. (2004). Decentralization, and Privatization of Education in Africa: Which Option for Nigeria? Special Issue of International Review of Education, 50(3/4): 307-323.

Geo-JaJa, M.A. and Mangum, G. (2003). Economic Adjustment, Education, and Human Resource Development in Africa: The Case in Nigeria. International Review of Education, 49(3/4): 293-318.

Heyneman, S. (1997). The Quality of Education in the Middle East and North Africa (MENA). International Journal of Educational Development 17 (4): 449-466.

International Monetary Fund. (2004). Report on the Evaluation of the Poverty Reduction Strategy Papers (PRSPS) and the Poverty Reduction and Growth Facility (PRGF), July 6, Washington DC: IMF.

Jolly, R. (2005). Human Development and Neo-liberalism Paradigms Compared, in Fukuda-Parr, Sakiko \& A. K. Shiva Kumar (eds.) Readings In Human Development: Concepts, Measures And Policies For A Development Paradigm, pp. 106-116. Oxford University Press, Oxford

Jones, T. and Hardstaff, M. (2005). Denying Democracy: How the IMF and the World Bank take Power from the People. World Development Movement, London, United Kingdom.

McMichael, P. (1996). The Rise of the Development Project, In [editors ] Development and Social Change: A Global Perspective (pp. 15-43). Thousand Oaks, CA: Pine Forge Press. 
McGinn, N. and Cummings, W. K (Eds.). (1997). International Handbook of Education and Development: Preparing Schools, Students and Nations in the Twenty-first Century, New York: Elsevier Science, Inc. (pp. 17-31)

Rio+ 10 News, (2002). Poverty in Nigeria: an Overview of the Underlying Causes. WSSD must take steps on the Universal Poverty question. Volume2, Issue 1 JulySeptember 2002.

Sala-I-Martin, Xavier and Subramanian, A. (2003). Addressing the Natural Resource Curse: An Illustration from Nigeria., IMF working paper WP/03/139 July. Washington DC: IMF.

Sen, A.K. (1992). Inequality Reexamined. Oxford: Clarendon Press.

Stewart, F., Ranis, G. and Ramirez, A. (2000). Economic Growth and Human Development', World Development, 28(2), 197-219.

Townsend, P. (1993). The International Analysis of Poverty. Hemel Hempstead: Harvester Wheatsheaf.

UNDP. (2006). Niger Delta Human Development Report: Impediments to Development in the Niger Delta. UNDP, Lagos, Nigeria.

UNDP. (2006). Human Development Report 2006. United Nations Development Program. New York :UNDP.

United Nations (2006). Human Development Report 2006 335. United Nations Development Program. New York: UNDP.

World Bank. (2005). Economic Growth in the 1990s: Learning from a Decade of Reform, Washington DC.: World Bank.

Professor Macleans A. Geo-JaJa is an economist in the McKay School of Education at Brigham Young University, where he teachers Economics of Education. Currently he is working with Beijing Normal University, China to develop Teacher Development Programs for China's Transformed education system. In 2006, he was appointed consulting member to the Editorial Board of World Congress of Comparative Education Societies (WCCES) and the International Review of Education (IRE) a journal of UNESCO.

Dr. Steve Azaiki, was the pioneer Commissioner for Agriculture and Natural Resources in Bayelsa State from 1997-1999. He served as the Secretary to Bayelsa State Government from 2002- 2005. He is the founder and President of the World Environmental Movement for Africa. 